\title{
IDENTIFICATION THE WAYS OF COUNTERACTION OF THE THREATS TO THE FINANCIAL SECURITY OF HIGH-TECH ENTERPRISES
}

\author{
Vasil FRANCHUK ${ }^{1}{ }^{*}$, Oleg OMELCHUK ${ }^{\circledR 2}{ }^{2}$, Stepan MELNYK ${ }^{(13}$, \\ Mykhailo KELMAN ${ }^{1}$, Oksana MYKYTYUK ${ }^{10} 5$ \\ ${ }^{1}$ Vice-rector, Lviv State University of Internal Affairs, Lviv, Ukraine \\ ${ }^{2}$ Rector, Khmelnytsky University of Management and Law, Khmelnytsky, Ukraine \\ ${ }^{3}$ Faculty number 2, Lviv State University of Internal Affairs, Lviv, Ukraine \\ ${ }^{4}$ Institute of Law and Psychology, Lviv Polytechnic National University, Lviv, Ukraine \\ ${ }^{5}$ Faculty of Media Communications and Entrepreneurship, Ukrainian Academy of Printing, Lviv, Ukraine \\ E-mails: ${ }^{1}$ __franchuk@yahoo.com (corresponding author); ${ }^{2}$ oleg_omelchuk@i.ua; \\ 3stepan_melnyk@i.ua; ${ }^{4} m y k h a i l o \_k e l m a n @ i . u a ;{ }^{5}$ omykytyuk@i.ua
}

Received 18 September 2019; accepted 02 December 2019

\begin{abstract}
Indicated key external and internal threats have a profound effect on the process of ensuring the financial security of the enterprise. Therefore, the important step is the application the mechanism of counteraction to the influence of external and internal threats. The mechanism for countering threats to the financial security of a high-tech enterprise, distinct the existing ones, combines a certain essence and hierarchical ordering of the influence of key external and internal threats, involves targeted tracking of changes in the operational environment, identification of the moment of occurrence of threats, prediction of possible results of their implementation, regulating the choice of the established option actions (adaptive, active and protective), control over security, result from the application of which is the rapid adaptation to possible changes, to neutralize the negative impact and response to threats of action in order to maintain the necessary level of financial security of the enterprise. The results of the study can be used in the practical activities of enterprises in the high-tech sector of the economy.
\end{abstract}

Keywords: financial security, high-tech enterprises, threats, mechanism.

JEL Classification: D21, D81, D82, G32.

\section{Introduction}

From today's perspective, market economy in Ukraine are characterized by a critical level of uncertainty and unpredictability of changes in the conditions of economic activity of enterprises. All this caused by many variables, such as: the monopolization of most markets, the imperfection of the legislative framework, pressure from regulatory authorities, insufficient support for local authorities, increased competition from foreign producers, reduced purchasing power of the population, and the like. In these conditions, for each enterprise, an effectively functioning system of financial security becomes vitally important, and in its structure, as the most important component, is a financial security system whose main task is not only to preserve financial resources, but also to create a safe environment for permanent business development.

The business climate in Ukraine are determined by a significantly unpredictable changes of the external environment and the lack of sufficient experience of competitive survival in such conditions of enterprises as independent socio-economic systems, which makes it difficult not only to manage each business entity, but also making quick and effective respond to a diminution of security level under the influence of threats of different nature and scale, which may result in the occurrence of signs of a crisis, and further ban of insolvency. High-tech enterprises have not only a strategic role for each individual country but also for the global economy as a whole, since they are the driving force

${ }^{*}$ Corresponding author. E-mail: v_franchuk@yahoo.com 
of scientific and technological progress. Therefore, solving the problem of identifying threats in order to use this information to further development of adequate protection programs to improve the management of the financial security of high-tech enterprises is relevant.

It should be noted that among all threats to the financial security of high-tech enterprises, in our opinion, those that concern to the financial sphere require special attention. The reasons for applying this approach is that the implementation of threats in the labour or technical, technological and other components of economic security ultimately becomes apparent through the negative change in financial indicators, that is, it entails the emergence of crisis situations in the field of financial security.

The process of ensuring the financial security of hightech enterprises has a number of significant features and one of the main ones requires focusing on the study of the impact of external and internal threats.

\section{Literature review}

The relevance and problems of ensuring the financial security of the enterprises are considered as worldwide. In the J. Zwolak study's (2017) demonstrates how financial security is important for any type of enterprise, from large to small. Also, it is interesting to highlight the main parameters that characterize the essence of the financial security of the enterprise. The results of his research suggest that there are a number of external and internal threats that cause a decrease in key parameters of the financial security of the enterprise.

Haber et al. (2018) conducted research to determine the level of financial security and the possibility of its forecasting. Given the level of financial security in our study, we seek to predict the impact of threats and counteract it.

Countering external and internal threats as the basis of the goal of managing the financial security of the enterprise was considered by Burkaltseva et al. (2017). They noted that it is threats that create the biggest problem for the financial security management system of the enterprise. We agree with this statement and that is why we have chose this topic of our research.

The importance of countering the influence of external and internal threats to the financial security of the enterprise has always bothered scientists. For example, Davydenko (2015) noted that ensuring financial security of both the enterprise and the state as a whole is impossible without an adequate response to the negative impact of threats. We cannot, disagree, and therefore, we propose in our study the development of a solution to this problem by constructing the mechanisms of counteraction the external and internal threats to the financial security of the enterprise.

A significant amount of scientific work has been devoted to problems of ensuring the financial security of the enterprise. The separate issue is the question of determining which is the current state of financial security at the enterprise and how significantly the threats affect it. Khudoliei (2018), based on the results of his research, offers an integrated method for determining the current state of the enterprise's financial security in order to identify the significant impact of threats. However, our study has differences and suggests that a list of threats has been defined in such a way that they can be better addressed.

Many modern studies are devoted to the study of the impact of external and internal threats on the financial security of the enterprise. For example, O. Biliomistniy et al. (2017), by constructing a three-dimensional regression surface, were able to establish a causal relationship between external and internal factors affecting the financial security of the enterprise. In our case, research involves the use of another method, namely graph theory and the mathematical establishment of the degree of influence on the security state.

The work of Ramskyi and Solonko (2018) is devoted to the study of external and internal threats to the mechanism of forming the financial security of the enterprise. They examined in more detail the issue of the importance of the financial security of the enterprise and how the process of ensuring could substantially depend on the effective counteraction of the negative impact of the external and internal functioning environment. Our study also confirms the fact how significant the influence of external and internal threats on the state of security of the enterprise is and offers appropriate measures to counter this influence.

Through strategic planning, countering external and internal threats to financial security, enterprises are considered by Rushchyshyn et al. (2017). Through the formation of an appropriate strategy, the authors propose consistently counteract the negative impact. However, we believe that the influence of threats should be streamlined and countermeasures need not only be strategic but also tactical.

How external and internal threats affect the financial security management of enterprises in Eastern Europe were investigated by Britchenko et al. (2018). They offer a whole range of measures to counter existing threats to the financial security of the enterprise. Our study has differences, because through a mathematical apparatus that allows you to streamline the influence of external and internal threats and more carefully select the appropriate countermeasures.

An interesting study is presented by Metelenko (2018), which formed the concept of a model for assessing the financial security of an enterprise taking into account the influence of external and internal threats on economic activity. The mechanism we have proposed is different because it takes into account threats that affect the financial activities of the enterprise more and may be part of the overall enterprise management system. 
Not least interesting is the study of Novikov and Novikova (2014), who presented their approach, which allows, through a group of indicators and factor analysis, determine the main external and internal factors and the type of their influence on the financial security of the enterprise. Developing such ideas, we propose to concentrate precisely on the negative impact of external and internal threats on the financial security of the enterprise in order to find ways to counter it.

Counteraction to external and internal threats to the financial security of the enterprise is not always active. Sometimes the influence of external threats is not controlled to the extent that there is a need to adapt the enterprise to such an impact. In this context, interesting studies by Vasyltsiv et al. (2012) offer an appropriate support strategy that allows them to adapt as much as possible to environmental conditions.

It is no secret that the financial security of the enterprise remains in the shadow of economic security, but more and more scientists agree that it is impossible to ensure the security of the entire enterprise without financial security. Hightech enterprises are very sensitive to the impact of external and internal threats to financial security. Due to the large scale of production and dependence on effective management, they should clearly understand how dangerous this effect is. That is why, we offer a mathematical solution to the problem.

\section{Research model and data}

High-tech enterprises in Ukraine are designed to produce the latest and advanced technologies. Unfortunately, not all knowledge-intensive industries of Ukraine can boast of high results. One of the reasons is the high number of various external threats that have a negative impact on them. The process of ensuring the financial security of high-tech enterprise has a number of essential features and one of the main ones requires focusing on the study of the influence of external threats. Only a timely response to changes in the security level under the influence of threats allows for a certain time period to prepare and implement protective programs, in turn, involves the consolidation of financial, material, labor, informational and other resources, the development of operational and strategic decisions and the like. Therefore, information on the possibility of implementing certain threats, the data on the materiality of the influence of certain of them, allow us to choose the most optimal protective response option as a basis for ensuring a high level of financial security, and preserving business in general.

According to the results of the analytical study, which was based on a survey of experts from among the leading specialists of high-tech enterprise of Ukraine (this group of experts includes experienced workers in the high-tech enterprises with high experience), the study of scientific papers on this topic (analysis of modern scientific work allowed generalizing and systematizing the existing external threats) and the synthesis of information from the State Statistics Service of Ukraine (official statistical information on high-tech enterprises demonstrates the main financial indicators and their dynamics, allows better see the main financial problems) identified and characterized the set of the most significant external threats that had a direct impact on financial security of high-tech enterprise in 2015-2018.

For illustrative purpose, the names of certain threats are supplemented by their mathematical notation (Table 1).

Table 1. The main external threats to the financial security of high-tech enterprises (source: developed by author)

\begin{tabular}{|c|l|}
\hline $\begin{array}{c}\text { Mathematical } \\
\text { notation }\end{array}$ & \multicolumn{1}{|c|}{ Threats } \\
\hline$q_{1}$ & State monetary and financial system \\
\hline$q_{2}$ & Level of development of the state legal system \\
\hline$q_{3}$ & $\begin{array}{l}\text { Illegal activities of representatives of regulatory } \\
\text { and law enforcement agencies }\end{array}$ \\
\hline$q_{4}$ & $\begin{array}{l}\text { Purchase of shares, debts of the enterprise } \\
\text { by undesirable partners as a prerequisite for } \\
\text { further raider seizure }\end{array}$ \\
\hline$q_{5}$ & $\begin{array}{l}\text { Illegal activities of criminal structures and } \\
\text { competitors }\end{array}$ \\
\hline$q_{6}$ & $\begin{array}{l}\text { Level of interest rates on loans from } \\
\text { commercial banks }\end{array}$ \\
\hline$q_{7}$ & $\begin{array}{l}\text { The volume of the domestic market and } \\
\text { increased competition from foreign producers }\end{array}$ \\
\hline
\end{tabular}

Thus, the totality of these threats (Table 1) makes up the set $Q=\{q 1, q 2, q 3, q 4, q 5, q 6, q 7\}$. The set of $Q$ threats and possible interrelations between them are presented in the form of a binary matrix of dependence of dimension $7 \times 7$ elements, its construction is reduced to filling the Table 2 binary elements which are determined according to the following rule (1):

$$
q_{i j}=\left\{\begin{array}{l}
1, \text { if } i \text { affects on } j \\
0, \text { otherwise }
\end{array}\right\} .
$$

The formulation and solution of the problem of constructing the connected graph between the listed threats can be carried out by using the means of graph theory and systems analysis methods (Arefieva et al. 2011, Liamets and Teviashev 2004, Saaiti 1993).

On the basis of the dependence matrix, we built the oriented connected graph between external threats to the financial security of high-tech enterprises (Figure 1), at the vertices of which elements of the set $\mathrm{Q}$ are placed, whose arcs connect adjacent pairs of vertices (qi, qj), or which the relationship is determined (Table 2). 
Table 2. Matrix of dependence of external threats to the financial security of high-tech enterprises (source: developed by author)

\begin{tabular}{|c|c|c|c|c|c|c|c|}
\hline$q_{i j}$ & $q_{1}$ & $q_{2}$ & $q_{3}$ & $q_{4}$ & $q_{5}$ & $q_{6}$ & $q_{7}$ \\
\hline$q_{1}$ & 0 & 0 & 0 & 1 & 1 & 0 & 1 \\
\hline$q_{2}$ & 0 & 0 & 0 & 0 & 0 & 0 & 0 \\
\hline$q_{3}$ & 0 & 0 & 0 & 0 & 0 & 0 & 0 \\
\hline$q_{4}$ & 0 & 0 & 0 & 0 & 0 & 0 & 0 \\
\hline$q_{5}$ & 0 & 1 & 1 & 1 & 0 & 0 & 0 \\
\hline$q_{6}$ & 1 & 0 & 0 & 1 & 1 & 0 & 0 \\
\hline$q_{7}$ & 0 & 0 & 0 & 0 & 1 & 0 & 0 \\
\hline
\end{tabular}

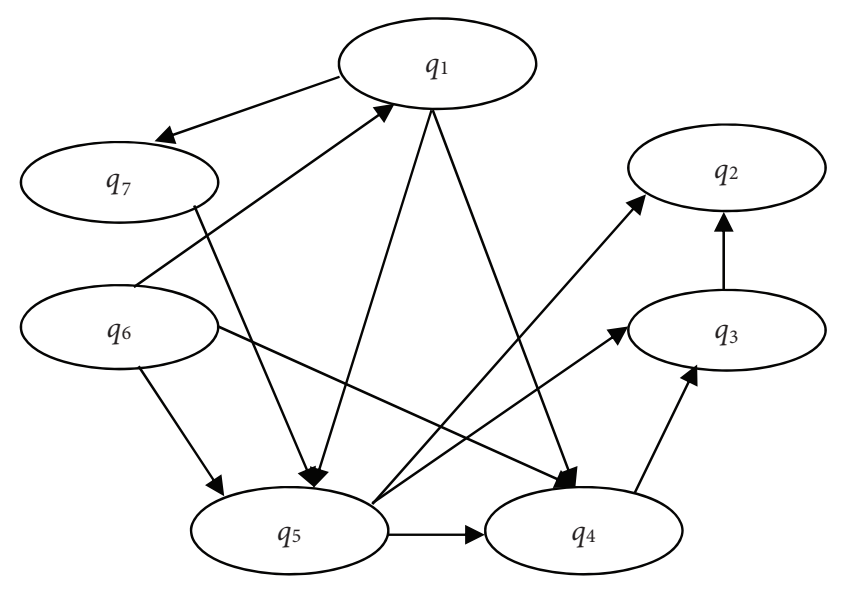

Figure 1. Connected graph between external threats to the financial security of high-tech enterprises (source: developed by author)

It should be noted that despite studies of the activities of enterprises specializing in one type of activity - high-tech, similar parameters of economic activity, that is, the assortment is the amount of net income from sales, balance sheet currency, the average number of employees, etc., the list of threats was characterized by a significant difference. Only as a result of the application of an expert survey with repeated reconciliation of the results, it became possible to isolate the internal threats that were characteristic of most domestic high-tech enterprises in 2015-2018.
Table 3. The Main Internal Threats to the Financial Security of High-Tech Enterprises (source: developed by author)

\begin{tabular}{|c|l|}
\hline $\begin{array}{c}\text { Mathematical } \\
\text { notation }\end{array}$ & \multicolumn{1}{|c|}{ Threats } \\
\hline$g_{1}$ & $\begin{array}{l}\text { Decrease in quality and increase in the size of } \\
\text { receivables and payables }\end{array}$ \\
\hline$g_{2}$ & Working capital deficit \\
\hline$g_{3}$ & Low liquidity of enterprise assets \\
\hline$g_{4}$ & Decrease in profitability of the main activity \\
\hline$g_{5}$ & Sales revenue reduction \\
\hline$g_{6}$ & Cost increase \\
\hline$g_{7}$ & Dependence on external sources of financing \\
\hline
\end{tabular}

For illustrative purpose, the names of the identified threats are supplemented by their mathematical notation (Table 3).

So, the set of internal threats to the financial security of the enterprise (Table 3 ) is the set $G=\{g 1, g 2, g 3, g 4, g 5, g 6, g 7\}$. We will present the set of threats $G$ and possible interrelations between them in the form of a binary dependence matrix of dimension $7 \times 7$ elements, its construction is reduced to filling out the Table 4 on the basis of which, in turn, we construct a graph of connections (Figure 2) between the internal threats to the financial security of a high-tech enterprise.

Table 4. Matrix of dependence of internal threats to the financial security of high-tech enterprises (source: developed by author)

\begin{tabular}{|l|c|c|c|c|c|c|c|}
\hline$g_{i j}$ & $g_{1}$ & $g_{2}$ & $g_{3}$ & $g_{4}$ & $g_{5}$ & $g_{6}$ & $g_{7}$ \\
\hline$g_{1}$ & 0 & 0 & 0 & 1 & 0 & 1 \\
\hline$g_{2}$ & 1 & 0 & 0 & 0 & 1 & 0 & 0 \\
\hline$g_{3}$ & 1 & 1 & 0 & 1 & 0 & 0 \\
\hline$g_{4}$ & 0 & 0 & 0 & 0 & 1 & 0 & 0 \\
\hline$g_{5}$ & 0 & 0 & 0 & 0 & 0 & 0 & 0 \\
\hline$g_{6}$ & 1 & 1 & 1 & 0 & 0 & 0 \\
\hline$g_{7}$ & 0 & 0 & 0 & 1 & 0 & 0 \\
\hline
\end{tabular}




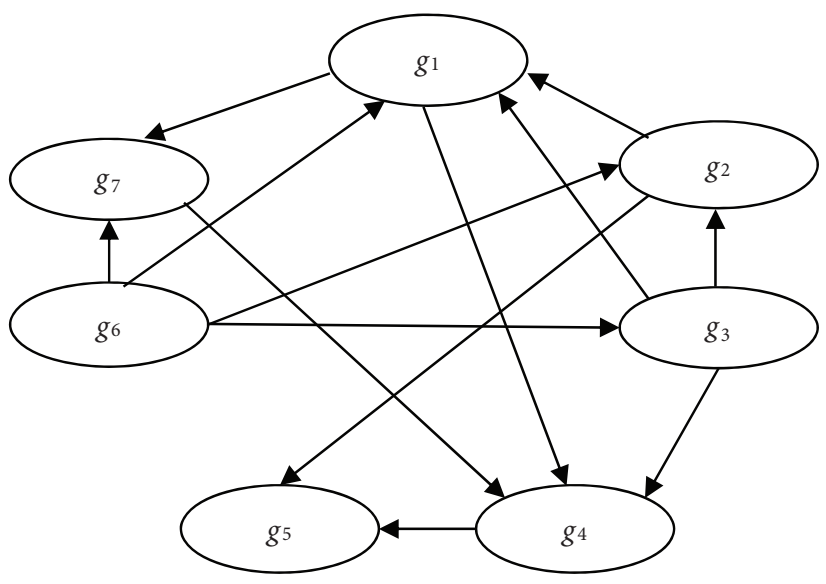

Figure 2. Connected graph between internal threats to the financial security of high-tech enterprises (source: developed by author)

\section{Results and discussions}

Based on the graph presented (Figure 1), we built a binary reachability matrix (Table 5 ) of dimension $7 \times 7$ elements for the set of vertices $Q$.

The intersection of the subsets of the vertices reachable and the vertices of the predecessors of the connected graph (Figure 1), that is, the subset (2):

$$
R\left(q_{i}\right)=S\left(q_{i}\right) \cap P\left(q_{i}\right) ;
$$

the vertices of which are not reached from any of the vertices of the set $Q$, the remaining ones determine a certain level of priority hierarchy of the action of the threats indicated by these vertices. An additional condition for this is to ensure equality (3):

$$
P\left(q_{i}\right)=R\left(q_{i}\right) .
$$

Performing a combination of the above actions gives the first level (the lowest in terms of the importance of influencing the process under study) of the threat hierarchy. To determine it on the basis of the reachability matrix (Table 5), we built an iterative table to form the first hierarchical level of external threats to financial security (Table 6).

In the second column of the table we enter the subset $S(q i)$ - the numbers of reachable vertices, or the numbers
Table 6. Iterative table of formation the first hierarchical level of external threats of financial security of high-tech enterprises (source: developed by author)

\begin{tabular}{|c|c|c|c|}
\hline$q_{i}$ & $S\left(q_{i}\right)$ & $\mathrm{P}\left(q_{i}\right)$ & $S\left(q_{i}\right) \cap \mathrm{P}\left(q_{i}\right)$ \\
\hline 1 & $1,2,3,4,5,7$ & 1,6 & 1 \\
\hline 2 & 2 & $1,2,3,4,5,6,7$ & 2 \\
\hline 3 & 2,3 & $1,3,4,5,6,7$ & 3 \\
\hline 4 & $2,3,4$ & $1,4,5,6,7$ & 4 \\
\hline 5 & $2,3,4,5$ & $1,5,6,7$ & 5 \\
\hline 6 & $1,2,3,4,5,6,7$ & 6 & 6 \\
\hline 7 & 7 & $1,6,7$ & 7 \\
\hline
\end{tabular}

of the unit elements of the corresponding rows of the reachability matrix; the third column defines a subset of the vertices of the predecessors $P(q i)$ - the numbers of the unit elements of the columns of this matrix. In this case, the dependence (3) means the fulfillment of the condition of equality of the numbers of threats specified in the second and third columns of the table, resulting in the fourth column of the table, as a result of the calculations of the iteration table.

Equality (3) is fulfilled for the threat of $q 6$ - the level of interest rates on loans from commercial banks - this threat is the first lowest level in the hierarchy of external threats to financial security.

Next from Table 6 we withdraw row 6 , and in $1-5$ and 7 th lines number 6 . We will receive the Table 7 , which is the basis for calculating the second iteration of finding the threat numbers, determining the next level of the hierarchy.

Table 7. Iterative table of formation the second hierarchical level of external threats of financial security of high-tech enterprises (source: developed by author)

\begin{tabular}{|c|c|c|c|}
\hline$q_{i}$ & $S\left(q_{i}\right)$ & $P\left(q_{i}\right)$ & $S\left(q_{i}\right) \cap P\left(q_{i}\right)$ \\
\hline 1 & $1,2,3,4,5,7$ & 1 & 1 \\
\hline 2 & 2 & $1,2,3,4,5,7$ & 2 \\
\hline 3 & 2,3 & $1,3,4,5,7$ & 3 \\
\hline 4 & $2,3,4$ & $1,4,5,7$ & 4 \\
\hline 5 & $2,3,4,5$ & $1,5,7$ & 5 \\
\hline 7 & 7 & 1,7 & 7 \\
\hline
\end{tabular}

\begin{tabular}{|c|c|c|c|c|c|c|c|}
\hline $\mathrm{q}_{\mathrm{ij}}$ & $q_{1}$ & $q_{2}$ & $q_{3}$ & $q_{4}$ & $q_{5}$ & $q_{6}$ & $q_{7}$ \\
\hline$q_{1}$ & 1 & 1 & 1 & 1 & 1 & 0 & 1 \\
\hline$q_{2}$ & 0 & 1 & 0 & 0 & 0 & 0 & 0 \\
\hline$q_{3}$ & 0 & 1 & 1 & 0 & 0 & 0 & 0 \\
\hline$q_{4}$ & 0 & 1 & 1 & 1 & 0 & 0 & 0 \\
\hline$q_{5}$ & 0 & 1 & 1 & 1 & 1 & 0 & 0 \\
\hline$q_{6}$ & 1 & 1 & 1 & 1 & 1 & 1 & 1 \\
\hline$q_{7}$ & 0 & 1 & 1 & 1 & 1 & 0 & 1 \\
\hline
\end{tabular}

Table 5. Reachability matrix of external threats to financial security of high-tech enterprises (source: developed by author) 
In the second iteration, equality (3) is fulfilled for the threat q1, which reflects the influence of the state monetary and financial system. This threat defines the next level of hierarchy. Therefore, from Table 7, delete line 1, and in lines 2-5 and 7, number 1 (Table 8).

Table 8. Iterative table of formation the third hierarchical level of external threats of financial security of high-tech enterprises (source: developed by author)

\begin{tabular}{|c|c|c|c|}
\hline$q_{i}$ & $S\left(q_{i}\right)$ & $P\left(q_{i}\right)$ & $S\left(q_{i}\right) \cap P\left(q_{i}\right)$ \\
\hline 2 & 2 & $2,3,4,5,7$ & 2 \\
\hline 3 & 2,3 & $3,4,5,7$ & 3 \\
\hline 4 & $2,3,4$ & $4,5,7$ & 4 \\
\hline 5 & $2,3,4,5$ & 5,7 & 5 \\
\hline 7 & 7 & 7 & 7 \\
\hline
\end{tabular}

In the third iteration, the next level forms the threat of $q_{7}$ - volume of the domestic market and increased competition from foreign producers. The corresponding row and the numbers in the columns in the Table 8 we withdraw and get Table 9 .

Table 9. Iterative table of formation the fourth hierarchical level of external threats of financial security of high-tech enterprises (source: developed by author)

\begin{tabular}{|c|c|c|c|}
\hline$q_{i}$ & $S\left(q_{i}\right)$ & $P\left(q_{i}\right)$ & $S\left(q_{i}\right) \cap P\left(q_{i}\right)$ \\
\hline 2 & 2 & $2,3,4,5$ & 2 \\
\hline 3 & 2,3 & $3,4,5$ & 3 \\
\hline 4 & $2,3,4$ & 4,5 & 4 \\
\hline 5 & $2,3,4,5$ & 5 & 5 \\
\hline
\end{tabular}

The next level is formed by the threat of $q 5$ - illegal activities of criminal structures and competitors. The corresponding row and the numbers in the columns are withdrawn.

Without a regular iteration table, it is clear that the following procedures will determine:

- the fifth level of the external threats hierarchy, which will be $q_{4}$ - purchase of shares, debts of the enterprise by undesirable partners as a prerequisite for further raider seizure;

- the sixth is the illegal activities of representatives of regulatory and law enforcement agencies $q_{3}$;

- the seventh is the level of development of the state legal system $q_{2}$.

By placing threats at certain levels, we obtain a hierarchically structured model (Table 10), which imitates the significance of external threats to the financial security of a high-tech enterprise.

In the constructed model (Table 10), the threats are placed from below upwards by increasing the priority of their influence on the process from the least significant to
Table 10. The hierarchy of external threats to the financial security of a high-tech enterprise (source: developed by author)

\begin{tabular}{|l|c|}
\hline Level of development of the state legal system $q_{2}$ & 1 \\
\hline $\begin{array}{l}\text { Illegal activities of representatives of regulatory and } \\
\text { law enforcement agencies } q_{3}\end{array}$ & 2 \\
\hline $\begin{array}{l}\text { Purchase of shares, debts of the enterprise by } \\
\text { undesirable partners as a prerequisite for further } \\
\text { raider seizure } q_{4}\end{array}$ & 3 \\
\hline $\begin{array}{l}\text { Illegal activities of criminal structures and competitors } \\
q_{5}\end{array}$ & 4 \\
\hline $\begin{array}{l}\text { The volume of the domestic market and increased } \\
\text { competition from foreign producers } q_{7}\end{array}$ & 5 \\
\hline State monetary and financial system $q_{1}$ & 6 \\
\hline $\begin{array}{l}\text { Level of interest rates on loans from commercial } \\
\text { banks } q_{6}\end{array}$ & 7 \\
\hline
\end{tabular}

the essential. It should be noted that the result of attributing the selected threats to the corresponding hierarchical level is objective as far as its reliability is ensured by using the well-known principles of the theory of systems analysis, the theory of modeling, methodology for improving and solving problems. In our case, the emergence of a specific threat at a certain level of the hierarchy essentially depends on the established connections between them (Table 2). Their change in number and nature will result in modification of the resulting model.

It should be noted that the theory of graphs was successfully applied in Shtangret and Sylkin (2018) work, but according to the results of the study, the anti-crisis mechanism was formed to counteract the influence of external and internal threats to the security of engineering enterprises. Considering the scientific contribution of our predecessors and the current state of the high-tech sector of the economy, we have improved and formed the mechanism of countering external threats to the financial security of high-tech enterprises in Figure 3. The proposed mechanism takes into account modern changes in the economy, and some of the identified external threats are the characteristic of high-tech enterprises.

We have provisionally identified two possible options to counter external threats to the financial security of high-tech enterprises:

- the first is an adaptation that can be applied to a group of external threats, the effects of which the high-tech enterprises cannot really counteract. Thus, any enterprise in the high-tech sector of the economy is not able to influence the monetary and financial system of the state, and its actual condition today can be described as crisis, that is, it is a clear threat to business structures. Counteraction to such threats is possible only through targeted adaptation to the possible impact, through forecasting the level and development of appropriate adaptation programs; 
- the second, defensive, can be applied to those external threats to the financial security of an enterprise, the development process of which the security subjects are able to control both by preventing the occurrence of defensive measures through the implementation and minimizing possible losses.

Despite the chosen option, the management of a hightech enterprise should effectively use the available information resources. Demonstration and coverage of the current state of the enterprise in the mass media will make it possible to make the better adaptation to any political and economic

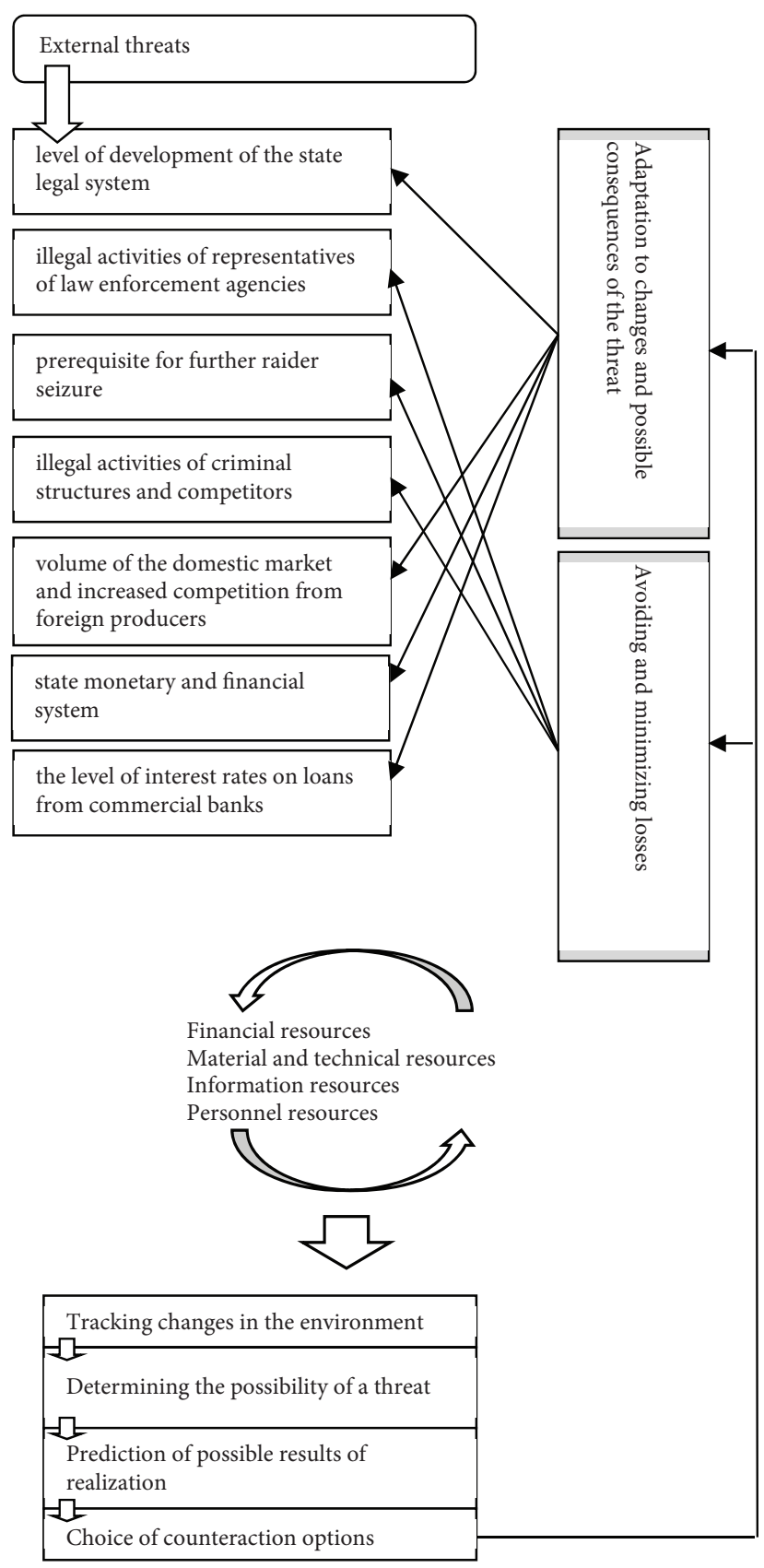

Figure 3. The mechanism of countering external threats to the financial security of high-tech enterprises (source: developed by author) changes. In addition, enterprises in this sector of the economy should present the products on their websites and at various videos in detail and more.

Based on the graph presented above (Figure 2), we construct a binary matrix of reachability of dimension $7 \times 7$ elements for the set of vertices $G$, which is used to implement an iterative algorithm for generating threat importance levels. The calculation for internal threats occurs similarly to external threats and skipping those steps, we formed a hierarchy of internal threats to the financial security of a high-tech enterprise (Table 11).

Table 11. The hierarchy of internal threats to the financial security of a high-tech enterprise (source: developed by author)

\begin{tabular}{|l|c|}
\hline Dependence on external sources of financing $g_{7}$ & 1 \\
\hline Cost increase $g_{6}$ & 2 \\
\hline Sales revenue reduction $g_{5}$ & 3 \\
\hline $\begin{array}{l}\text { Decrease in quality and increase in the size of } \\
\text { receivables and payables } g_{1}\end{array}$ & 4 \\
\hline Working capital deficit $g_{2}$ & 5 \\
\hline Decrease in profitability of the main activity $g_{4}$ & 6 \\
\hline Low liquidity of enterprise assets $g_{3}$ & 7 \\
\hline
\end{tabular}

According to the results of hierarchical streamlining of internal threats to the financial security of a high-tech enterprise, it is advisable to note that the results obtained may be different in relation to a specific company, but this cannot be considered a drawback, but rather an advantage that makes the development of protective measures not only taking into account individual characteristics, but also industry development trends (Figure 4).

We have conditionally established a possible variant of counteracting internal threats to the financial security of the enterprise: active - recommended for use in relation to internal threats. An effective financial security system is able to counteract internal threats.

\section{Conclusions}

The current state of international economic relations provides for a parity relationship in the production and exchange of high-tech products. Countries that are striving to develop their own production potential are actively introducing high-tech solutions into production. In the economies of leading countries, there is a steady increase in the importance of knowledge-intensive industries and high technologies. This is evidenced by the fact that the cost of companies specializing in the production of high-tech products on the stock market exceeds the value of the largest enterprises of resource-extracting and processing industries.

Regarding threats, there is a clear interaction of a separate specialized unit and (or) official with the financial service, 
economic department, accounting, etc. being able to prevent the occurrence, control the development and eliminate their consequences.

Summarizing the study, we had noted that in order to ensure the necessary level of financial security for the engineering enterprise, which is necessary for the functioning and development, it is necessary to effectively counteract to the internal and external threats by applying the most appropriate option. The option to counter threats depends on
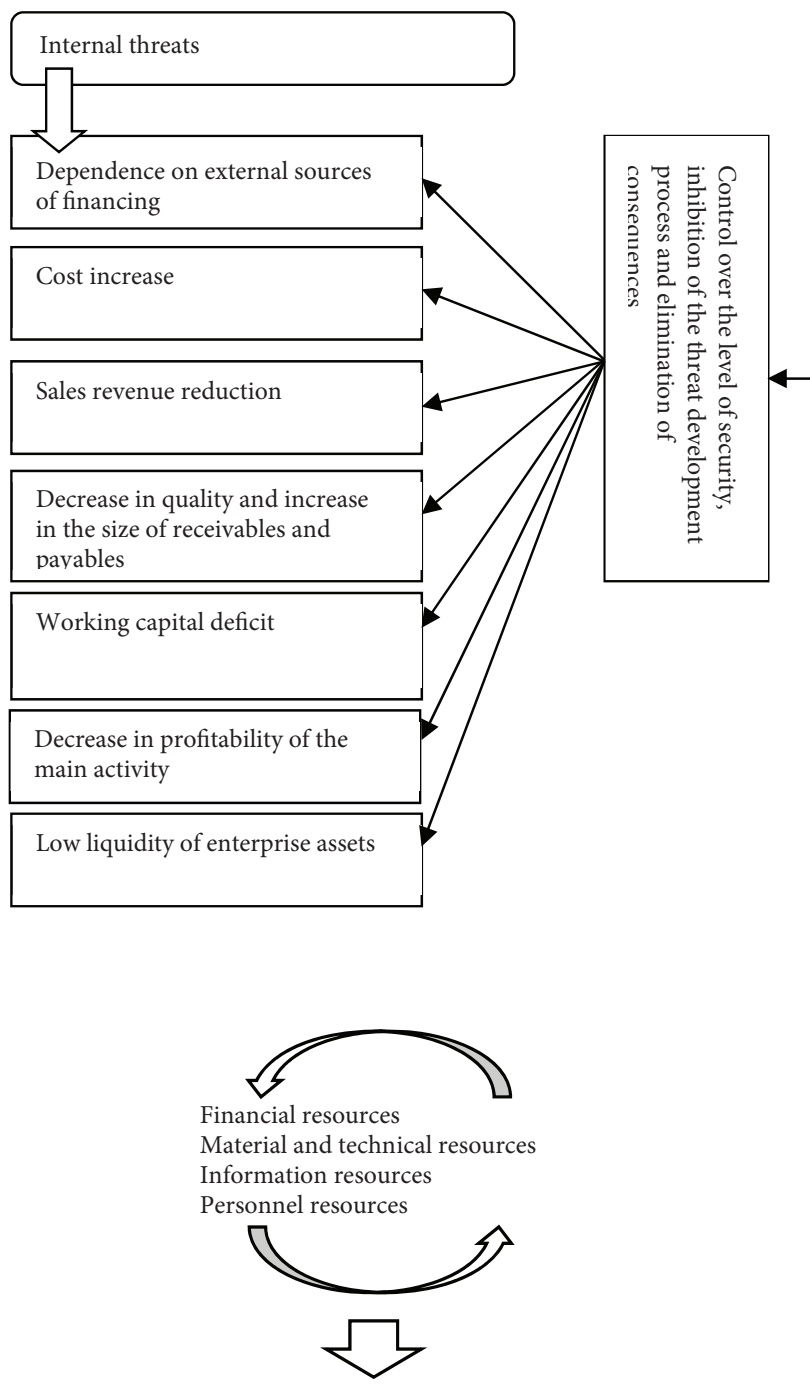

Tracking changes in the environment
Determining the possibility of a threat
realization

Figure 4. The mechanism of countering internal threats to the financial security of high-tech enterprises (source: developed by author) the nature and priority of the influence of a particular threat and the protective capabilities of the enterprise, expressed in the effectiveness of the formation of a system of financial security and the availability of necessary resources.

Taking into account the scientific contribution of scientists, also, using mathematical methods, we sought to create a mechanism to counter the influence of threats, also we improved and expanded it, formed a mechanism to counter threats based on the results of hierarchical optimization of key external threats. We believe that dividing the countermeasures into two parts is optimal. In our case, such options are the choice of an adaptive or protective option to counter the influence of external threats.

The study is not without limitations. At the moment, a mechanism for countering internal and external threats is presented that can be applied in practice only for enterprises in the high-tech sector of the economy. In the future, more attention should be paid to its expansion into other areas of business.

\section{Author contributions}

The authors contributed equally.

\section{Disclosure statement}

The authors do not have any conflict of interest.

\section{References}

Arefieva O, Senkivskyi V, Shtangret A, Melnikov O (2011) Building models of key threats to the knowledge economy in Ukraine. Scientific Notes 2 (35): 52-67.

Biliomistniy O, Bilomistna I, Galushko Y (2017) Influence external and internal factors to financial security of enterprise. Financial and Credic Activity: Problems of Theory and Practice 1 (22). https://doi.org/10.18371/fcaptp.v1i22.109935

Burkaltseva D, Borsch L, Blazhevich O, Frolova E, Labonin I (2017) Financial and economic security of business as a primary element in the economic system. Revista: Espacios 38 (33): 3-20.

Britchenko I, Bohomolova N, Kravchenko O, Pinchuk S (2018) assessment of the determinats of financial security of railways in Ukraine. Financial and credit activity: Problems of Theory and Practice 4 (27).

https://doi.org/10.18371/fcaptp.v4i27.154109

Davydenko N (2015) Genesis of enterprise financial security. Economic Processes Management: International Scientific E-Journal (2) http://epm.fem.sumdu.edu.ua/download/2015_2/2015_2_3.pdf

Haber J, Bukhtiarova A, Chorna S, Lastremska O (2018) Forecasting the level of financial security of the country on the example of Ukraine. Investment Management and Financial Innovations 15 (3): 304-317. https://doi.org/10.21511/imfi.15(3).2018.25

Khudoliei L (2018) Assessment of the level of financial security of machine-building enterprises of Zaporizhzhia region with 
the help of integral-rating method. Eureka: Social and Humanities (1): 38-45.

https://doi.org/10.21303/2504-5571.2018.00546

Liamets V, Teviashev A (2004) System analysis. Introductory course (2 ed). Kharkov. National University of Radio Electronics, $448 \mathrm{p}$.

Metelenko N (2018) Conceptual model for assessing financial safety in the system of economic security of industrial enterprise. Management and entrepreneurship: Trends of Development 4 (06).

https://doi.org/10.26661/2522-1566/2018-4/06-11

Novikov A, Novikova M (2014) Modeling of financial and economic security of transport enterprises based on factor analysis. Nauka ta Progress Transport 6 (54). https://doi.org/10.15802/stp2014/32769

Ramskyi A, Solonko A (2018) Mechanism of formation of financial security of an enterprise. European Scientific Journal of Economic and Financial Innovation European Association of Economists 1: 14-20. https://doi.org/10.32750/2018-0102 Rushchyshyn N, Nikonenko U, Kostak Z (2017) Formation of financial security of the enterprise based on strategic planning. Baltic Journal of Economic Studies (3): 231-233. https://doi.org/10.30525/2256-0742/2017-3-4-231-237

Saaiti T (1993) Decision making: hierarchy analysis method. Radio and Communication, $278 \mathrm{p}$.

Shtangret A, Sylkin O (2018) Anti-crisis mechanism of countering the impact of external and internal threats of the financial security of machine-bulding enterprises. Social Legal Studios (2): 123-131.

Vasyltsiv TH, Voloshyn VI, Vasyltsiv TH (Ed.) (2012) Financial and economic security of Ukraine: Strategies and mechanisms to ensure: the monograph. Lviv: Liha-Pres, 386 http:// lv.niss.gov.ua/content/articles/files/mono_2012-d47ce.pdf

Zwolak J (2017) The financial security of small- and mediumsized enterprises in Poland. Ekonomski Pregled 68 (4): 399412. 